\title{
An evaluation of IFIs impact on EU countries budget deficits
}

\author{
Bogdan CĂPRARU \\ George GEORGESCU \\ Nicu SPRINCEAN
}


Romanian Fiscal Council Working Papers are written by members of the board and technical staff of Romanian Fiscal Council and from time to time by other economists.

Disclaimer: The opinions expressed in this paper belong to the authors and do not reflect necessarily the position of the Romanian Fiscal Council. It is also valid for possible errors which belong strictly to the authors.

(C) Romanian Fiscal Council 2020 


\title{
An evaluation of IFls impact on EU countries budget deficits
}

\author{
Bogdan CĂPRARU ${ }^{1}$, George GEORGESCU ${ }^{2}$, Nicu SPRINCEAN ${ }^{3}$
}

\begin{abstract}
This paper explores the impact of the independent fiscal institutions on public budget deficit in the European Union. We employ a dynamic panel model for the period 2000-2019 and find that these fiscal watchdogs have a positive and significant influence on general government balance for European Union Member States, resulting in smaller public budget deficits. The findings maintain their significance regardless of the year of accession to the European Union (old vs. new members) or euro area status (euro area vs. non-euro area members). However, we find that the independent fiscal institutions play a much important role for countries that established their fiscal institutions before 2013. Moreover, we document that during systemic and banking crises these independent fiscal councils can help reducing public budget deficits. Our results are robust to a variety of specifications and models, including alternative definitions of government balance and after controlling for a set of institutional characteristics.
\end{abstract}

Key words: Fiscal Balance; Independent Fiscal Institutions; Public Budget Deficit

JEL codes: E62, H60

\footnotetext{
1 Bogdan Căpraru is Ph.D. habil., full professor of Finance at the Faculty of Economics and Business Administration, Alexandru I. Cuza University-lași and member of the Fiscal Council.

${ }^{2}$ George Georgescu is senior researcher at the National Institute for Economic Research Costin C. Kirițescu Romanian Academy and member of the Fiscal Council.

${ }^{3}$ Nicu Sprincean is Ph.D., assistant at the Faculty of Economics and Business Administration, Alexandru I. Cuza University-lași.
} 


\section{Table of contents}

$\begin{array}{lr}\text { 1. Introduction } & 5\end{array}$

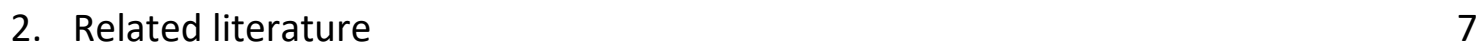

3. Sample, data, and methodology $r 9$

3.1. Sample and data $\quad 9$

$\begin{array}{lll}3.2 & \text { Econometric framework } & 9\end{array}$

$\begin{array}{lr}\text { 4. Empirical results } & 11\end{array}$

$\begin{array}{lll}4.1 & \text { Descriptive statistics } & 11\end{array}$

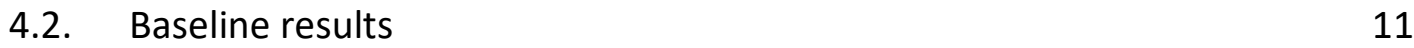

$\begin{array}{ll}\text { 4.3. Further analysis } & 12\end{array}$

$\begin{array}{lr}\text { 5. Conclusions } & 14\end{array}$

$\begin{array}{lr}\text { References } & 15\end{array}$ 


\section{Introduction}

In this study we assess the budgetary implications of Independent Fiscal Institutions (IFIs) in the European Union (EU) countries aiming at evaluating whether they have an impact on fiscal balances and how significant it is. The approach of our analysis relies on the principles of fiscal responsibility which should guide all executive politics and governances of public finance on the long run, avoiding excessive fiscal deficits and unsustainable debt levels.

In our interconnected world and even more in the EU, where the economic governance is largely based on policy coordination in many areas, we think that any fiscal and/or debt slippage in one country could trigger cross-border chain reactions. Lessons from global financial crisis and sovereign debt crisis showed that too much was spent on fiscal frameworks reforms and less on strengthening the democratic control of political decisions that contributed to their trigger, ignoring the intertemporal budgetary constraints and the interests of future generations.

The issue of political budget cycle mitigating, discussed first by Nordhaus (1975) and further developed, among others, by Rogoff and Sibert (1988), has been recently reviewed by Wiplosz (2019) who advocate that, because the election times encourage deficits, not often corrected later on, the fiscal discipline is not a choice but a general rule in terms of time inconsistency and end-of-legislature conundrum, in order to hold politicians and governments accountable for their budgetary actions and performances.

At the level of the European Union, the policies in main areas are aligned and coordinated by the EU Directives transposing into national laws, except for the field of fiscal and budgetary policy, which has been left to the discretion of each Member State, any proposal for EU action in the tax field requiring to consider the principles of subsidiarity and proportionality. Going over the debates carried out under the generic of "Fiscal Union" creation that should work together with the Monetary Union, the impact of the 2007-2009 financial crisis showed a major vulnerability of the European construction due to the lack of fiscal policies coordination.

Although the history of some IFls is older (see the review undertaken by Georgescu and Căpraru, 2020), the new coordinates for their establishment in the EU and euro area, are based on the post-crisis fiscal surveillance framework, consistent with the introduction of numerical fiscal rules and related mechanisms for correcting the deviation from these, in which IFIs are a strong pillar.

Under these circumstances, the IFIs got increasingly more analytic interest from academics, practitioners and decision makers. The rationale behind this lies in the political nature of fiscal policy as allocative, distributive and stabilization functions, not always easy to reconcile and with direct impact on economic growth, financial balances and fiscal discipline (European Fiscal Board, 2019). In terms of monitoring and assessments objectivity, in relation to the government outcomes of the fiscal policy, the clear advantage of IFIs is based on the competence and nonpartisanship of their members.

The IFIs role in addressing excessive deficits was approached by various authors and international organizations from different perspectives. Without being exhaustive, after 
arguing the idea of delegating some aspects of the fiscal policy and its monitoring to independent authorities (Alessina et al., 2007; Debrun et al., 2009; Calmfors and Wren-Lewis, 2011), IFIs' capacity to improve the public understanding of the fiscal policy quality (Darvas and Kostyleva, 2011; Beetsma and Debrun, 2016) or performance (Coletta et al., 2015; Beetsma et al., 2018) has been emphasized. The subject of incorporating similar principles, standards or minimum criteria on national IFIs design for ensuring their independence and increase in operational capacity also stood out (Kopits, 2011; OECD, 2014; Wyplosz et al. 2019). Due to some dysfunctions in the European fiscal frameworks, proposals arguing the need for their reforming under the monitoring of national fiscal councils and/or at the EU level have been put forward (Claeys et al., 2016; Kamps and Leiner-Killinger, 2019; Dullien et al., 2020).

However, it should be stressed that most of the research attention has been captured by analysis and assessments of IFIs impact on government fiscal performances, which are discussed in the next section of the paper and represent also our research subject. Here, we underline only the difficulty of such approaches at the level of EU IFIs network due to their heterogeneity and particular characteristics, which complicates the attempts to extract trends, generally valid conclusions and common good practices.

In this paper, we contribute to the extant literature, firstly, by constructing our time-varying dataset of fiscal frameworks covering the period 2000-2019 for all 27 EU countries that have established IFIs. Also, we assess the impact of IFIs by controlling for euro area membership or the time a particular country joined the EU community.

We use as a proxy for IFIs the dummy variable that expresses not only the year of establishment, but also the year in which the respective IFI went through a process of institutional reform. To the best of our knowledge there are no other studies that have done an assessment considering IFIs' institutional reform. We evaluate the impact of IFIs on fiscal performance depending on the years of IFIs operating. There is only one paper that deals with this subject, but in a different way. Beetsma et al. (2018) include a differentiation between "veteran" and new institutions and between councils that emanated from a homegrown process as opposed to those introduced under external pressure.

Another contribution is the fact that we consider as fiscal performance variables three different types of public budget deficits like General Fiscal Balance, Primary Balance (primary deficit), and Cyclically-Adjusted Fiscal Balance (structural deficit). In this way we can evaluate more in depth the impact of EU IFIs on fiscal outcomes. For robustness check we introduce some country level institutional and governance variables, among other, financial development and governance index.

Last but not least we evaluate the EU IFIs impact on fiscal performances taking into account different types of systemic and banking crises episodes. In this respect we employ the interaction regression.

The paper is structured as follows: Section 2 reviews the current discussion on Independent Fiscal Institutions, in Section 3 we present the sample, data and methodology, in Section 4 we discuss the empirical results, and Section 5 concludes. 


\section{Related literature}

The economic literature on IFIs is becoming abundant, but the number of studies is reduced when we consider the papers that use empirical models to explain the impact of IFIs on fiscal outcomes. Overall, the literature suggests that IFIs have a clear and significant positive influence on fiscal performance.

Prior research varies depending on the variables employed to represent fiscal performance and IFIs presence. For example, for fiscal outcomes one uses the general government balance (Franek and Postula, 2019), the cyclically-adjusted balance (Debrun et al., 2012, WildowiczGiegiel, 2019), the primary balance (Debrun and Kinda, 2014; Nerlich and Reuter, 2013), the cyclically-adjusted primary balance (Debrun and Kumar, 2007; Fabrizio and Mody, 2006; Nerlich and Reuter, 2013), fiscal forecasting accuracy (Debrun et al., 2017; Beetsma et al., 2018), or government borrowing costs (Pappas and Kostakis, 2020).

When it comes to IFIs' proxies, studies are split as follows: studies that use dummy variable that takes the value of 1 if the fiscal council in a particular year was established and afterwards, and 0 otherwise (Maltritz and Wüste, 2015; Beetsma et al., 2018; Pappas and Kostakis, 2020;) or for some institutional characteristics (Debrun et al., 2012; Nerlich and Reuter, 2013; Debrun and Kinda, 2014; Debrun et al., 2017;), and studies that introduce in the regression equation composite indices (Fabrizio and Mody, 2006; Debrun and Kumar, 2007; Wildowicz-Giegiel, 2019; Franek and Postula, 2019).

Beetsma et al.'s (2018) evidence on $27 \mathrm{EU}$ countries suggests that the presence of a fiscal council is associated with more accurate and possibly less optimistic fiscal forecasts. Thus, IFIs reduce forecasting biases and improve the precision of forecasts of the primary balance. This is consistent with the "signal-enhancement" role of IFIs theorized by Beetsma et al. (2017): better informed voters and veto players in the budgetary process can provide stronger incentives to policymakers to deliver sound policies. Pappas and Kostakis (2020) demonstrate that the establishment and the operation of IFIs is associated with lower government borrowing costs. They use as well a proxy for the role of IFIs a dummy variable found to be significant and with a negative sign. In their opinion, the rationale that explains this result may be that a strong fiscal framework with fiscal councils reinforces investors' confidence and increases the reduction of risk premiums on long-term government bonds. Maltritz and Wüste (2015) analyze the determinants of the budget balance of 27 EU countries from 1991 to 2011 in a panel approach, focusing on the effectiveness of fiscal rules and fiscal councils. While fiscal councils used as a dummy variable show no significant influence, they detect a significant positive impact of an interaction term between fiscal councils and a crisis dummy. Their results also show a positive and statistically significant effect on the primary balance of the interaction effect between fiscal rules and fiscal councils. They conclude that fiscal councils seem to work in countries with stronger fiscal rules, having a positive influence at least in times of financial distress.

Debrun and Kinda (2014), in a study on 58 advanced and developing economies, consider that the mere existence of fiscal councils is not by itself conducive to stronger fiscal balances. Their results suggest that certain characteristics of fiscal councils significantly impact fiscal performances. Key features for effective fiscal councils include: operational independence from politics, the provision or public assessment of budgetary forecasts, a strong presence in 
the public debate, and an explicit role in monitoring fiscal rules. Nerlich and Reuter (2013) find for a sample that covering the period 1990 to 2012 for 27 EU countries that the positive effect on the primary balance and on the cyclically-adjusted primary expenditures can be further strengthened by supporting the numerical fiscal rules with independent fiscal councils and an effective medium-term budgeting framework. The effect on the primary balance is twice as strong as in the case without a fiscal council and even three times as strong when complemented with an independent fiscal council and an effective medium-term budgeting framework.

Some papers measure the effect of IFIs' media presence on the cyclically-adjusted balance (Debrun et al, 2012), on the primary balance (Debrun and Kinda, 2014) and fiscal forecasting (Debrun et al., 2017). Debrun et al (2012) use simple panel regressions on EU-15 states for the years 1990-2004 to detect a relationship between the intensity of media reports referring to the fiscal council and two real-time fiscal policy indicators expected to be of interest for the fiscal council: the planned change in the cyclically-adjusted budget balance (CAB) at the beginning of the year and the first estimate of the deviation in the CAB with respect to plans. The first captures the degree of fiscal activism planned in the budget (stimulus or consolidation) and the second is interpreted as a symptom of slippages or over-performance during the budgetary year. Also, Debrun et al. (2017) propose to proxy the influence of IFIs on public debate on fiscal policy with direct measures of media presence. The sample includes seven continental European countries-Austria, Belgium, Germany, Denmark, Netherlands, Sweden, and Slovenia-over the period 2003-2010. The analysis investigates the planned change in the $C A B$ as a proxy for deliberate policy action, and on the forecast error, which could reflect unexpected shocks affecting the budget or policy slippages.

Other studies use as proxy for IFIs some composite indices. Debrun and Kumar (2007) apply the analytical framework proposed in Debrun et al. (2005), and compile indices of different features of fiscal councils that might be regarded as likely to be related to fiscal performance (the cyclically-adjusted primary balance). Their estimations demonstrate a strong relationship between the de jure influence exerted by fiscal councils from 22 EU members and their perceived impact on fiscal performance - evidence that was complemented by a positive relationship between formal guarantees of independence and their perceived impact. They also find that the presence of fiscal councils is associated with tighter rules. Fabrizio and Mody (2006), using a panel data of 10 new and potential EU members over the period 1997-2003, show that the primary-balance-to-GDP ratio seems to be positive correlated with the debtto-GDP ratio, the fiscal institution index, the inflation rate, the Fiscal Rule index, and the openness of the economy. In the same way, Wildowicz-Giegiel (2019) assess the impact of fiscal councils using as proxy the Scope Index of Fiscal Institutions, augmented by fiscal rules (index of fiscal rules) and medium-term budget frameworks (the medium-term budgetary framework index) on cyclically-adjusted budget balance. These results proved that fiscal institutions contribute to the improvement of fiscal performance. Their sample includes the EU-28 countries in years 2006-2017. Franek and Postula (2019) construct a synthetic index that takes into account the strength of both the fiscal rules and the medium-term budgetary framework and independent fiscal institutions as proxy for fiscal instruments. Their estimation of relationship between the use of fiscal instruments and fiscal outcomes in EU countries in the period from 2004 to 2016 indicates a statistically significant and positive impact of the use of fiscal instruments on the general government balance-to- GDP ratio. 


\section{Sample, data, and methodology}

\subsection{Sample and data}

We study the influence of the IFIs on public budget deficit in the 27 European Union Member States for a period that spans from 2000 to $2019 .{ }^{4}$ We use three alternative measures for public budget deficit, i.e., Fiscal Balance (government revenues minus government expenses, as a percent of GDP), Primary Balance (government revenues minus government expenses net of the public sector debt interest expenditure, as a percent of GDP), and CyclicallyAdjusted Fiscal Balance (government revenues minus government expenses net of one-off and temporary measures, as a percent of potential GDP). The main source of data is the annual macro-economic database of the European Commission's Directorate General for Economic and Financial Affairs (AMECO). Table A1 from the Appendix presents in detail all variables used in the analysis and their sources, whereas Table $A 2$ exhibits the list of countries together with the year of establishment of fiscal councils.

\subsection{Econometric framework}

We employ a dynamic panel estimator assuming that past values of public budget deficit have an impact on its current behavior, with the following specification:

$$
\begin{aligned}
& \text { Balance }_{j, t}=\alpha_{1} \times \text { Balance }_{j, t-1}+\alpha_{2} \times \text { Fiscal Council }_{j, t}+\alpha_{3} \times \boldsymbol{X}_{\boldsymbol{j}, t}+\alpha_{4} \times \\
& \text { Institutional Characteristics }_{j, t}+\varepsilon_{j, t}
\end{aligned}
$$

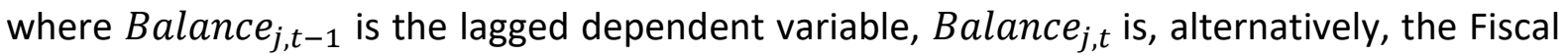
Balance, Primary Balance and Cyclically-Adjusted Fiscal Balance, respectively for country $j$ at time $t$, Fiscal Council $_{j, t}$ is a dummy variable that takes the value of one if a country $j$ has established a fiscal council at time $t$, and zero otherwise, $\boldsymbol{X}_{\boldsymbol{j}, \boldsymbol{t}}$ is a $(\mathrm{k} \times 1)$ vector of countryspecific control variables (i.e., Real GDP Growth, Gross Debt to GDP, Inflation and Unemployment), Institutional Characteristics ${ }_{j, t}$ are, alternatively, a set of institutional variables (i.e., Financial Openness, Financial Development Index and Governance Index, respectively), and $\varepsilon_{j, t}$ is the disturbance term which is assumed to be independent for each $j$ over all $t$. Also, we include in the analysis a Global Crisis $t_{t}$ variable that takes the value of 1 if the year is before 2008, and 0 otherwise. The lagged dependent variable is, by construction, endogeneous. Nickel (1981) shows that the least-squares dummy variable (LSDV) estimator is not consistent for finite $T$ in autoregressive panel data models. One way to address this issue is to use the instrumental variable (IV) and generalized method of moment (GMM) estimators. However, they tend to be inefficient in small sample where $N$ is not so large. ${ }^{5}$ Kiviet (1995) and subsequently Bun and Kiviet (2003) proposed a bias-corrected least-squares dummy variable (LSDVC) in which they approximate the bias from the LSDV, and show in Monte Carlo simulations that the LSDVC outperforms the IV-GMM estimators in terms of bias and root mean squared error (Bruno, 2005a). Bruno (2005b) extends the LSDVC technique to dynamic unbalanced panels setting and constructs a consistent estimator by using the

\footnotetext{
${ }^{4}$ We consider all member states at the end of 2019, including the United Kingdom. With the exception of Poland, all other countries have established a fiscal council before 2019. See Table A2 from the Appendix for details. ${ }^{5}$ Windmeijer (2005) derived a finite-sample correction to the variance-covariance matrix for the two-step GMM estimator. However, we do not employ a GMM estimator with the Windmeijer (2005) correction because, due to our small cross-sectional dimension, the number of instruments exceeds the number of groups.
} 
bootstrap variance-covariance matrix. In order to make the bias correction possible, we initialize the LSDVC with the Blundell-Bond estimator (see Blundell and Bond, 1998 for details). ${ }^{6}$

Further, we develop the empirical analysis using alternative specifications and controlling for sample characteristics. First, several fiscal councils went through a process of reform (i.e., fiscal councils from Austria, Belgium, Denmark and the Netherlands). For instance, in Austria, the Government Debt Committee was succeeded by the Fiscal Advisory Council in 2013. The FISK law of 2013 extends the mandate, aiming to comply with new European Union requirements while supporting compliance with the multidimensional national fiscal rules through monitoring ongoing fiscal developments, adherence to country-specific numerical fiscal rules and providing its own fiscal forecasts, assessments and recommendations (OECD, 2015). Thus, we consider the year when the reform was implemented as an alternative for the year of IFIs' creation.

Second, we investigate whether the results hold for old vs. new Member States, considering countries that joined the EU before 2004 as old, and the others as new. We construct two dummy variables reflecting these aspects and interact them with the Fiscal Council variable in the benchmark regression, as described by Eq. (2) below.

Third, in a similar approach, we differentiate between euro area and non-euro area members and derive two dummy variables, denoting their euro area status, and interact them with the Fiscal Council variable in the benchmark specification. The model can be represented as follows:

Balance $_{j, t}=\beta_{1} \times$ Balance $_{j, t-1}+\beta_{2} \times$ Fiscal Council $_{j, t} \times$ Member $_{j, t}+\beta_{4} \times \boldsymbol{X}_{\boldsymbol{j}, t}+u_{j, t}$ (2)

where Member $_{j, t}$ are, alternatively, dummy variables reflecting old and new EU members, and euro area and non-euro area members, respectively.

Lastly, we divide fiscal councils according to their year of foundation. IFIs that were created before $2013^{7}$ - the median of the sample - are deemed as old, whereas those established starting with 2013 are considered new. Also, 2013 coincides with the end of sovereign debt crisis in Europe (Cornille et al., 2019), and the entry into force of the Treaty on Stability, Coordination and Governance in the Economic and Monetary Union, including the Fiscal Compact. This Treaty defines the fiscal surveillance framework setting up numerical fiscal rules, based on reference values for the ratio between government deficit and public debt to GDP, structural deficit and medium-term objective, to which an expenditure benchmark was added. Article 3 paragraph 2 of the Treaty stipulates that the Contracting Parties shall put in place at national level the role and independence of the institutions responsible for monitoring compliance with the fiscal rules, i.e., of IFIs. In cases of deviations from the fiscal

\footnotetext{
${ }^{6}$ Other consistent estimators are Anderson-Hsiao (Anderson and Hsiao, 1982) and Arellano-Bond (Arellano and Bond, 1991). We employ these alternative specifications for robustness checks.

${ }^{7}$ Beetsma et al. (2018) undertake a similar assessment using 2007 as the cutoff year. We do not take the same approach because this results in a sample that is too small (only four countries created their independent fiscal councils before 2007: Austria, Belgium, Denmark, and the Netherlands) and our variable of interest, i.e.,

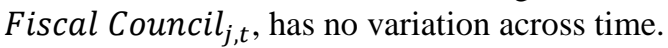


rules, correction mechanisms and procedures for adjustment strategies are provided, including financial sanctions for non-compliance.

In our analysis of whether IFIs affect the impact of selected variables on measures of public budget deficit, we focus on the effect of systemic and banking crises by including their interaction with Fiscal Council in the benchmark regression. Systemic crises are defined according to the European Systemic Risk Board (see Lo Duca et al., 2017 for details), whereas banking crises follow the approach of Laeven and Valencia (2020). The model has the following specification:

Balance $_{j, t}=\beta_{1} \times$ Balance $_{j, t-1}+\beta_{2} \times$ Fiscal Council $_{j, t} \times$ Crisis $_{j, t}+\beta_{4} \times \boldsymbol{X}_{j, t}+u_{j, t}$ (3)

where Crisis $_{j, t}$ is a dichotomous variable that takes the value of one if country $j$ experienced a systemic crisis ${ }^{8}$ or banking crisis $^{9}$ in year $t$, and zero otherwise.

\section{Empirical results}

\subsection{Descriptive statistics}

Table 1 presents the descriptive statistics of the variables used in the empirical analysis. We can note that Fiscal Balance ranges from -32\% (Ireland in 2010) to 5.7\% (Luxembourg in 2001) with a mean of approximately $-2.4 \%$ and a standard deviation of $3.5 \%$; the minimum value of Primary Balance is $-29.2 \%$ and the maximum is $7.5 \%$ for the same countries with a mean of $0.17 \%$ and a standard deviation of 3.18\%. Cyclically-Adjusted Fiscal Balance takes values in the range from $-30.82 \%$ to $6.24 \%$ with an average of $-2.34 \%$ and a standard deviation of $3.96 \%$.

[Table 1 goes here]

Overall, on average over the 2000-2019 period, the 27 European Union members had public budget deficits. During this time we experienced the global financial crisis and the European sovereign debt crisis which severely affected public finances where public authorities were forced to step in, making use of different intervention measures and instruments in order to alleviate the consequences and to avoid a major systemic crisis (see Goodhart, 2008; Praet and Nguyen, 2008; Panetta et al., 2009). The negative aftermath of the crisis episodes can also be found in the reduced level of economic growth and increased amount of public debt.

\subsection{Baseline results}

The benchmark results exhibited in Table 2 show a positive and significant impact of IFIs on fiscal balances, meaning that these fiscal watchdogs contribute to a better position of public finances, resulting in smaller public budget deficits (i.e., a greater difference between government revenues and expenses). More important, we document that this positive and

\footnotetext{
${ }^{8}$ Acharya (2009) notes that in a systemic crisis many banks fail together, or if one bank's failure propagates as a contagion causing the failure of many banks.

${ }^{9}$ The banking system has been the underlying cause that triggered the systemic failure through the so-called subprime mortgages. Laeven and Valencia (2020) undertake a well-documented analysis in which they assess all the banking crises from 1970 to 2017. The authors find that in this period more than 150 systemic banking crises affected the world economies, reflecting, inter alia, deficient regulations and poor supervision frameworks.
} 
significant effect holds across all alternative measures of fiscal balance, i.e., the difference between general government revenues and expenses (Fiscal Balance), after excluding the public sector debt interest expenditure (Primary Balance), and after deducting the cyclical components of government spending and revenues (Cyclically-Adjusted Fiscal Balance). Thus, under all these scenarios, fiscal councils play a major role in preserving sound public finances. ${ }^{10}$

[Table 2 goes here]

In terms of control variables, in countries with higher economic growth ${ }^{11}$ (Real GDP) public deficits as measured by Fiscal Balance and Primary Balance are smaller. The significant influence of Gross Public Debt to GDP variable is present only in the case of Primary Balance across all five models which was to expected considering the deduction of public sector debt interest expenditure from the general Fiscal Balance.

Our inferences remain robust after controlling for different institutional characteristics (Financial Openness, Financial Development and Governance (Models (2) to (4)) and crisis conditions (Model (5)). Global financial crisis, as expected, has a negative and significant impact at the $1 \%$ level on all public balances.

\subsection{Further analysis}

In this section, we conduct further investigations by developing the empirical analysis using alternative specifications and employing some interactions with the Fiscal Council variable.

Four independent fiscal councils from our sample went through a process of reform, namely IFIs from Austria, Belgium, Denmark and the Netherlands. We create new dummy variables for these countries that take the value of one starting with the year of reform implementation and afterwards, and zero otherwise and replace them in the initial Fiscal Council $_{j, t}$ variable. The estimated results are showcased in Table 3 . We can note more significant findings compared to those from the benchmark model (Table 2), meaning that the positive influence of IFIs is more pronounced if we take into account the reform. This could be explained by the decades of experience and expertise of the four countries in fiscal and budgetary matters, long before the IFIs reform, and the high credibility of their outcomes. It is noteworthy that during 2000-2019 these countries recorded fiscal surpluses or deficits below three percent of GDP, except for few post-crisis years, and the primary balances registered surpluses in most years.

\section{[Table 3 goes here]}

The influence of IFIs on public budget deficits can differ for old and new EU members. Old members, with mature democracies, have stronger and better institutions, a more prudent stance of the fiscal policy, and much more exigent voters compared to new members, and thus an enhanced capacity to manage their public finances. Given their relative recent

\footnotetext{
${ }^{10}$ By employing the other two consistent estimators, i.e., Anderson-Hsiao (Anderson and Hsiao, 1982) and Arellano-Bond (Arellano and Bond, 1991) the robust findings do not change. The output is available upon request. ${ }^{11}$ Other studies (see e.g., Beetsma et al., 2018) employ the output gap to control for the cyclical behavior of fiscal policy. As a robustness assessment, we use the output gap computed as percent of the potential GDP from AMECO. The main results maintain their significance and are available upon request.
} 
transition process to free-market economy, the incumbent governments from the new EU members are less fiscal responsible and more biased to use public budget as a tool to gain new mandates through procyclical fiscal policies and discretionary public spending and tax cuts. We find the same positive and significant impact of the fiscal councils on public budget deficit for both old and new Member States. This suggests also the role of the Fiscal Compact, considering the matrix of fiscal adjustment requirements and the related country-specific Medium Term Objectives (MTOs), many countries, with lower debt-to-GDP ratio, managing to reach the MTO which stood as an anchor for the public finances.

\section{[Table 4 goes here]}

Next, we conduct the analysis by controlling for euro area membership. To become a member of the euro zone, countries have to meet the Maastricht convergence criteria, including sustainable public finances, with a budget deficit below $3 \%$ of GDP and the public debt-toGDP ratio below $60 \%$. Thus, sound public finances are a key prerequisite for joining the euro area. As a consequence, independent fiscal councils may have a more noticeable influence for non-euro area countries which are supposed to be more interested in adopting euro, at least those less developed from Central and Eastern Europe (for example, Bulgaria and Croatia are set to join euro area, being currently accepted into ERM-II). We document that being a member of euro area does not influence the outcome we found in the benchmark model (Table 4). Thus, the positive and significant impact of IFIs on public balances holds irrespective of the euro area association.

In a similar approach to Beetsma et al. (2018), we want to explore whether the year of creation of these IFIs matters for sound public finances. We differentiate between fiscal councils established before 2013 - the median of the sample - and those founded starting with 2013. The empirical results are shown in Table 5 and Table 6, respectively. For fiscal councils established before 2013 (Table 5) the effect is strongly significant at the $1 \%$ level across all fiscal balances, whereas for those founded starting with 2013 the influence on public budget deficit lacks statistical significance, in which mattered the fact that during 20142018 the EU experienced a fiscal consolidation process and in 2019 almost all countries ended the budgetary execution in surplus or with fiscal deficits below $3 \%$. The explanation may also lie in the time needed to become an effective institution, strengthening its reputation and credibility, the main pillars of IFIs soft power to influence the budgetary process.

[Table 5 goes here]

[Table 6 goes here]

Lastly, we perform an interaction regression described in Eq. (3) considering systemic and banking crises. When a crisis hits an economy, governments intervene to ease the negative consequences by using public funds, thus putting a pressure on public budgets. Taking the example of the global financial crisis, the aftermath was so pernicious that was needed to spend trillions of euros (and dollars) of public funds to bail-out the distressed financial institutions, especially those deemed as "too-big-to-fail". We find that having an independent fiscal council during a systemic or banking crisis is beneficial for Fiscal Balance in the case of European Union Member States, where the interaction coefficients, Fiscal Council $\times$ Systemic Crisis and Fiscal Council $\times$ Banking Crisis are both statistically significant across several models, 
controlling for institutional characteristics. Thus, during systemic and banking crises the presence of an IFI is desirable to preserve sound public finances.

[Table 7 goes here]

\section{Conclusions}

In this paper we assess the impact of IFIs from the European Union Member States on the public budget deficit over the 2000-2019 period. Our robust results show a positive and significant effect of IFIs on public finances that holds across all alternative measures of fiscal balance (i.e., General Fiscal Balance, Primary Balance, and Cyclically-Adjusted Fiscal Balance). Thus, having and independent fiscal council is desirable for preserving sound public finances.

Further, we develop the empirical analysis using alternative specifications and control for different sample characteristics. The influence of the IFIs on public budget deficit has no bearing on key results after taking into account the time a particular country has been part of the European Union (old vs. new members) or its euro area status (euro area vs. non-euro area member). We also find that for fiscal councils established before 2013 (old IFIs) the effect is strongly significant across all public balances, whereas for those founded starting with 2013 (new IFIs) the influence on public budget deficit lacks statistical significance. Finally, we demonstrate that during systemic and banking crises the presence of an IFI can help governments to keep under control public budget deficits.

Considering our findings, we have some policy recommendations taking also into account the fiscal impact of COVID-19 pandemic triggered in 2020 under the circumstances of the EU's fiscal rules suspension (activation of the "general escape clause" within the Stability and Growth Pact), whose monitoring represents one of the main IFIs' tasks.

Despite so much evidence, revealed also by our study, of stronger national fiscal governance frameworks, with the notable contribution of IFIs, in providing sound public finances and mitigating procyclicality of fiscal policy, much remain to be done to increase their effectiveness on two major action layers.

First, the scope, magnitude and channels of exercising influence that defines IFIs operating power (legal basis, mandate, resources etc.), should be similar in the EU countries, in order to gain a multiplier force by interactions with feedback loops at national level, including crosscountry experiences and good practices, leading, through iterative changes, to a more harmonized legal framework and modus operandi which can help the creation of the still uncertain Fiscal Union.

Second, amid debates on reforming the fiscal governance and rules, including in relation with the post-COVID-19 and green economy, the need for concerted actions and responses from IFIs became obvious for the increase in their effectiveness, which would require coordination at EU level, implying significant changes in the design and enforcement of the EU framework for fiscal policies, within the EU IFIs network and the European Fiscal Board. 


\section{References}

Acharya, V., 2009. A theory of systemic risk and design of prudential bank regulation. Journal of Financial Stability 5, 224-255.

Alesina, A., Campante, F.R., Tabellini, G., 2008. Why is Fiscal Policy Often Procyclical? Journal of the European Economic Association 6, 1006-1036.

Anderson, T.W., Hsiao, C., 1982. Formulation and estimation of dynamic models using panel data. Journal of Econometrics 18, 47-82.

Arellano, M., Bond, S., 1991. Some Tests of Specification for Panel Data: Monte Carlo Evidence and an Application to Employment Equations. Review of Economic Studies 58, 277-297.

Beetsma M.W.R., J, Debrun, X., 2016. Fiscal Councils: Rationale and Effectiveness. IMF Working Paper 16/86.

Beetsma, M.W.R., J., Debrun, X., Fang, X., Kim, Y., Lledo, D. V., Mbaye, S., Zhang, X., 2018. Independent fiscal councils: recent trends and performance. IMF Working Paper 18/68.

Beetsma, R., Debrun, X., Sloof, R., 2017. The Political Economy of Fiscal Transparency and Independent Fiscal Councils. CEPR Discussion Paper No.12181.

Blundell, R., Bond, S., 1998. Initial conditions and moment restrictions in dynamic panel data models. Journal of Econometrics 87, 115-143.

Bruno, G.S.F., 2005a. Estimation and Inference in Dynamic Unbalanced Panel-data Models with a Small Number of Individuals. The Stata Journal 5, 473-500.

Bruno, G.S.F., 2005b. Approximating the bias of the LSDV estimator for dynamic unbalanced panel data models. Economics Letters 87, 361-366.

Bun, M.J.G., Kiviet, J.F., 2003. On the diminishing returns of higher-order terms in asymptotic expansions of bias. Economics Letters 79, 145-152.

Calmfors L, Wren-Lewis, S., 2011. Fiscal Councils. CEPR Economic Policy.

Chinn, M. D., Ito, H., 2008. A New Measure of Financial Openness. Journal of Comparative Policy Analysis: Research and Practice 10, 309-322.

Claeys, G., Darvas, Z., Leandro, A., 2016. A Proposal to Revive the European Fiscal Framework. Breugel Policy Contribution, Issue 2016/07.

Coletta, G., Graziano, C., Infantino, G., 2015. Do fiscal councils impact fiscal performance? Working Paper, Italy: Department of the Treasury, Ministry of Economy and Finance, 1.

Cornille, D., Rycx, F., Tojerow, I., 2019. Heterogeneous effects of credit constraints on SMEs' employment: Evidence from the European sovereign debt crisis. Journal of Financial Stability 41, 1-13. 
Darvas, Z., Kostyleva, V., 2011. The Fiscal and Monetary Institutions in CESEE Countries. Breugel Working Paper 2011/02.

Debrun, X., Gérard, M., Harris, J., 2017. Fiscal Watchdog and Sound Fiscal Policy: Is the Barking Loud Enough to Tame Politicians? in Gaspar, V., Gupta, S. and C. Mulas-Granados (eds.), Fiscal Politics, International Monetary Fund.

Debrun, X., Hauner, D., Kumar, M. S., 2005. Enhancing Fiscal Discipline: Is There a Role for Fiscal Agencies?, unpublished. International Monetary Fund.

Debrun, X., Hauner, D., Kumar, M.S., 2009. Independent Fiscal Agencies. Journal of Economic Surveys $23,44-81$.

Debrun, X., Kilda, T., 2014. Strengthening post-crisis fiscal credibility: fiscal councils on the rise. IMF Working Paper 14/58.

Debrun, X., Kumar, M.S., 2007. Fiscal Rules, Fiscal Councils and All That: Commitment Devices, Signaling Tools or Smokescreens?, in Bancad'Italia (ed.), Fiscal Policy: Current Issues and Challenges, papers presented at the Public Finance workshop held in Perugia, 29-31 March 2007, pp. 479-51.

Debrun, X., Zhang, Z., Lledó, V., 2017. The Fiscal Council Dataset: A Primer to the 2016 Vintage. Available at: http://www.imf.org/external/np/fad/council/.

Debrun, X., Gérard, M., Harris, J., 2012. Has the Time for Fiscal Councils Come at Last? OECD Conference Centre, Paris 23-24 February.

Dullien, S., Paetz, C., Watt, A., Watzka, S., 2020. Proposal for a reform of the EU's fiscal rules an economic governance. IMK Report, June.

European Fiscal Board, 2019. Independent Fiscal Institutions in the EU fiscal framework. Workshop 2019, Brussels.

Fabrizio, S., Mody, A., 2006. Can budget institutions counteract political indiscipline? Economic Policy 21, 690-739.

Franek, S., Postula, M., 2019. Measuring the strength of fiscal instruments and their effectiveness in improving the sustainability of public finances in European Union countries. Materials and Studies, Warsaw: National Bank of Poland, 334.

Georgescu G., Căpraru, B.S., 2020. Fiscal Councils in European Union. A short retrospective review and current challenges in terms of functionality and effectiveness. Romanian Fiscal Council Working Papers No. 2, May.

Goodhart, C.A.E., 2008. The regulatory response to the financial crisis. Journal of Financial Stability 4(4), 351-358.

Kamps C., Leiner-Killinger, N., 2019. Taking stock of the functioning of the EU fiscal rules and options for reform. ECB Occasional Paper Series No. 232. 
Kaufmann, D., Kraay, A., Mastruzzi, M., 2011. The Worldwide Governance Indicators: Methodology and Analytical Issues1. Hague Journal on the Rule of Law 3, 220-246.

Kiviet, J.F., 1995. On bias, inconsistency, and efficiency of various estimators in dynamic panel data models. Journal of Econometrics 68, 53-78.

Kopits, G., 2011. Independent Fiscal Institutions: Developing Good Practices. OECD Journal of Budgeting, Vol. 11/3.

Laeven, L., Valencia, F., 2020. Systemic Banking Crises Database II. IMF Economic Review 68, 307-361.

Lo Duca, M., Koban, A., Basten, M., Bengtsson, E., Klaus, B., Kusmierczyk, P., Lang, J.H., Detken, C., Peltonen, T., 2017. A new database for financial crises in European countries. ESRB Occasional Paper Series No. 13.

Maltritz, D., Wüste, S., 2015. Determinants of budget deficits in Europe: The role and relations of fiscal rules, fiscal councils, creative accounting and the Euro. Economic Modelling, Special Issue on Current Challenges on Macroeconomic Analysis and International Finance Modelling $48,222-236$.

Maltritz, D., Wüste, S., 2020. What Determines Fiscal Deficits in Europe? The Impact and Interaction of EMU Membership, Fiscal Rules, Fiscal Councils and Creative Accounting. Review of Economics 71, 15-41.

Nerlich, C., Reuter, W. H., 2013. The design of national fiscal frameworks and their budgetary impact. ECB Working Paper Series, 1588.

Nickell, S., 1981. Biases in Dynamic Models with Fixed Effects. Econometrica 49, 1417-1426.

Nordhaus, W.D., 1975. The Political Business Cycle. Review of Economic Studies 42, 169-190.

OECD, 2014. Recommendations on Principles for Independent Fiscal Institutions. OECD, Paris, February.

Panetta, F., Faeh, T., Grande, G., Ho, C., King, M., Levy, A., Signoretti, F., Taboga, M., Zaghini, A., 2009. An assessment of financial sector rescue programmes. BIS papers No. 48.

Pappas, A., Kostakis, I., 2020. The Driving Factors of EMU Government Bond Yields: The Role of Debt, Liquidity and Fiscal Councils. International Journal of Financial Studies 8, 53.

Praet, P., Nguyen, G., 2008. Overview of recent policy initiatives in response to the crisis. Journal of Financial Stability 4(4), 368-375.

Rogoff, K., Sibert, A., 1988. Elections and Macroeconomic Policy Cycles. Review of Economic Studies 55, 1-16.

Sahay, R., Cihak, M., N’Diaye, P.M., Barajas, A., Ayala Pena, D.B., Bi, R., Gao, Y., Kyobe, A.J., Nguyen, L., Saborowski, C., Svirydzenka, K., Yousefi, R., 2015. Rethinking Financial Deepening: Stability and Growth in Emerging. IMF Staff Discussion Notes No. 15/08. 
Wildowicz-Giegiel, A., 2019. The role of independent fiscal councils in improving fiscal performance of the European Union countries. Equilibrium. Quarterly Journal of Economics and Economic Policy 14(4), 611-630.

Windmeijer, F., 2005. A finite sample correction for the variance of linear efficient two-step GMM estimators. Journal of Econometrics 126, 25-51.

Wiplosz, C., Beetsma, R., Larch, M., Beuve, J., Darvas, Z., Delpeuch, S., Martin, P., Ragot, X., Steinbach, A., Busch, B., Matthes, J., 2019. Fiscal Rules for Europe. IFO DICE Report, Volume 17, Number 2. 
Table 1.

Summary statistics for the European Union countries for the 2000-2019 period.

\begin{tabular}{lrrrrrrrr}
\hline \hline & Mean & St. Dev. & p25 & Median & p75 & Min & Max & Obs. \\
\hline Fiscal Balance & -2.3664 & 3.5208 & -4.0488 & -2.1486 & -.0437 & -32.0633 & 5.6870 & 513 \\
Primary Balance & -0.1704 & 3.1827 & -1.5433 & 0.1406 & 1.6900 & -29.2328 & 7.5297 & 513 \\
Cyclically-Adjusted Balance & -2.3384 & 3.1568 & -3.9558 & -2.0640 & -0.4318 & -30.8260 & 6.2409 & 512 \\
\hline Fiscal Council & 0.4737 & 0.4998 & 0.0000 & 0.0000 & 1.0000 & 0.0000 & 1.0000 & 513 \\
\hline Real GDP Growth & 2.3435 & 3.4904 & 0.9562 & 2.3740 & 3.9895 & -14.8142 & 25.1625 & 513 \\
Gross Public Debt to GDP & 58.9834 & 34.6126 & 35.728 & 53.5072 & 78.7169 & 3.7655 & 181.2115 & 513 \\
Inflation & 2.5964 & 3.2665 & 1.0981 & 1.9828 & 3.3037 & -9.7299 & 37.9563 & 513 \\
Unemployment & 8.5526 & 4.2767 & 5.6000 & 7.5000 & 10.1000 & 2.0000 & 27.5000 \\
\hline Financial Openness & 0.9251 & 0.1708 & 1.0000 & 1.0000 & 1.0000 & 0.1650 & 1.0000 \\
Financial Development & 0.5797 & 0.2009 & 0.4100 & 0.6338 & 0.7451 & 0.1286 & 0.9472 \\
Governance Index & 1.0779 & 0.4926 & 0.7384 & 1.0566 & 1.4925 & 0.0068 & 1.9088 \\
Crisis & 0.6316 & 0.4828 & 0.0000 & 1.0000 & 1.0000 & 0.0000 & 4.0000 \\
\hline \hline
\end{tabular}

Note: This table presents the summary statistics of the variables used in the empirical analysis. A complete description of variables can be found in Table A1 from the Appendix. Statistics for control variables are based on the regression with Fiscal Balance as main dependent variable. 
Table 2.

Base results.

\begin{tabular}{|c|c|c|c|c|c|c|c|c|c|c|c|c|c|c|c|}
\hline & \multicolumn{5}{|c|}{ Fiscal Balance } & \multicolumn{5}{|c|}{ Primary Balance } & \multicolumn{5}{|c|}{ Cyclically-Adjusted Fiscal Balance } \\
\hline & (1) & (2) & (3) & (4) & (5) & (1) & (2) & (3) & (4) & (5) & (1) & (2) & (3) & (4) & $(5)$ \\
\hline \multirow[t]{2}{*}{ Dependent $(\mathrm{t}-1)$} & $0.6932^{* * * *}$ & $0.6848^{* * *}$ & $0.6862^{* * * *}$ & $0.6779 * * *$ & $0.6932 * * *$ & $0.6642 * * *$ & $0.6615^{* * * *}$ & $0.6631 * * *$ & $0.6578^{* * * *}$ & $0.6642^{* * * *}$ & $0.7322 * * *$ & $0.7254 * * *$ & $0.7327 * * *$ & $0.7239 * * *$ & $0.7322^{* * * *}$ \\
\hline & $(0.0449)$ & $(0.0436)$ & $(0.0430)$ & $(0.0471)$ & $(0.0449)$ & $(0.0442)$ & $(0.0428)$ & $(0.0433)$ & $(0.0475)$ & $(0.0442)$ & $(0.0390)$ & $(0.0430)$ & $(0.0422)$ & $(0.0429)$ & $(0.0390)$ \\
\hline \multirow[t]{2}{*}{ Fiscal Council } & $0.7581 * *$ & $0.8969^{* * *}$ & $0.9677 * * *$ & $0.9345^{* * * *}$ & $0.7581 * *$ & $0.7673 * *$ & $0.8699 * *$ & $0.9459^{* * * *}$ & $0.9144 * * *$ & $0.7673 * *$ & $0.7967 * *$ & $0.9416^{* * *}$ & $1.0050 * *$ & $0.9823 * * *$ & $0.7967 * *$ \\
\hline & $(0.3094)$ & $(0.3635)$ & $(0.3557)$ & $(0.3476)$ & $(0.3094)$ & $(0.3076)$ & $(0.3619)$ & $(0.3550)$ & $(0.3466)$ & $(0.3076)$ & $(0.3738)$ & $(0.3961)$ & $(0.4022)$ & $(0.3560)$ & $(0.3738)$ \\
\hline \multirow[t]{2}{*}{ Real GDP growth } & $0.1071 * * *$ & $0.0945 * *$ & $0.0933^{* *}$ & $0.0938^{* *}$ & $0.1071 * * *$ & $0.0789 * *$ & 0.0662 & $0.0665^{*}$ & 0.0671 & $0.0789 * *$ & $-0.1264 * * *$ & $-0.1387 * * *$ & $-0.1410 * * *$ & $-0.1433 * * *$ & $-0.1264 * * *$ \\
\hline & $(0.0391)$ & $(0.0481)$ & $(0.0392)$ & $(0.0462)$ & $(0.0391)$ & $(0.0390)$ & $(0.0479)$ & $(0.0391)$ & $(0.0461)$ & $(0.0390)$ & $(0.0411)$ & $(0.0441)$ & $(0.0412)$ & $(0.0476)$ & $(0.0411)$ \\
\hline \multirow[t]{2}{*}{ Gross Public Debt to GDP } & 0.0116 & 0.0089 & 0.0084 & 0.0065 & 0.0116 & $0.0242 * *$ & $0.0236^{* *}$ & $0.0223^{*}$ & $0.0207^{*}$ & $0.0242 * *$ & 0.0056 & 0.0037 & 0.0027 & -0.0003 & 0.0056 \\
\hline & $(0.0110)$ & $(0.0099)$ & $(0.0117)$ & $(0.0116)$ & $(0.0110)$ & $(0.0109)$ & $(0.0100)$ & (0.0117) & $(0.0114)$ & $(0.0109)$ & $(0.0116)$ & $(0.0132)$ & $(0.0111)$ & $(0.0118)$ & (0.0116) \\
\hline \multirow[t]{2}{*}{ Inflation } & 0.0467 & 0.0574 & 0.0402 & 0.0540 & 0.0467 & 0.0329 & 0.0432 & 0.0272 & 0.0358 & 0.0329 & 0.0644 & $0.0795 *$ & 0.0601 & 0.0817 & 0.0644 \\
\hline & $(0.0407)$ & $(0.0447)$ & $(0.0400)$ & $(0.0552)$ & $(0.0407)$ & $(0.0404)$ & $(0.0446)$ & $(0.0400)$ & $(0.0551)$ & $(0.0404)$ & $(0.0439)$ & $(0.0453)$ & $(0.0431)$ & $(0.0563)$ & $(0.0439)$ \\
\hline \multirow[t]{2}{*}{ Unemployment } & -0.0098 & -0.0067 & -0.0222 & -0.0392 & -0.0098 & -0.0389 & -0.0386 & -0.0503 & -0.0649 & -0.0389 & 0.0501 & 0.0607 & 0.0422 & 0.0238 & 0.0501 \\
\hline & $(0.0493)$ & $(0.0465)$ & $\begin{array}{l}(0.0530) \\
\end{array}$ & $(0.0491)$ & $(0.0493)$ & $(0.0487)$ & $\begin{array}{l}(0.0467) \\
\end{array}$ & $\begin{array}{l}(0.0533) \\
\end{array}$ & $\begin{array}{l}(0.0489) \\
\end{array}$ & $\begin{array}{l}(0.0487) \\
\end{array}$ & $\begin{array}{l}(0.0442) \\
\end{array}$ & $\begin{array}{l}(0.0526) \\
\end{array}$ & $(0.0542)$ & $(0.0496)$ & $(0.0442)$ \\
\hline \multirow[t]{2}{*}{ Financial Openness } & & 0.4015 & & & & & 0.5024 & & & & & 0.7080 & & & \\
\hline & & $(0.9118)$ & & & & & (0.8988) & & & & & $(1.1350)$ & & & \\
\hline \multirow[t]{2}{*}{ Financial Development } & & & -4.4273 & & & & & -3.8779 & & & & & -4.3187 & & \\
\hline & & & $(2.9399)$ & & & & & $(2.9365)$ & & & & & $(3.3556)$ & & \\
\hline \multirow[t]{2}{*}{ Governance Index } & & & & -1.6100 & & & & & $\begin{array}{l}-1.1793 \\
\end{array}$ & & & & & -2.2328 & \\
\hline & & & & (1.3894) & & & & & $(1.3674)$ & & & & & $(1.4354)$ & \\
\hline \multirow[t]{2}{*}{ Crisis } & & & & & $-3.1737^{* * * *}$ & & & & & $-3.6528^{* * * *}$ & & & & & $-2.2522 * * *$ \\
\hline & & & & & $(0.6920)$ & & & & & $(0.6931)$ & & & & & $(0.5900)$ \\
\hline Observations & 513 & 468 & 486 & 459 & 513 & 513 & 468 & 486 & 459 & 513 & 512 & 467 & 485 & 459 & 512 \\
\hline Countries & 27 & 26 & 27 & 27 & 27 & 27 & 26 & 27 & 27 & 27 & 27 & 26 & 27 & 27 & 27 \\
\hline Year FE & Yes & Yes & Yes & Yes & Yes & Yes & Yes & Yes & Yes & Yes & Yes & Yes & Yes & Yes & Yes \\
\hline
\end{tabular}

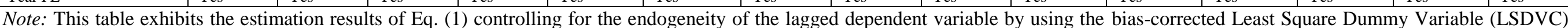

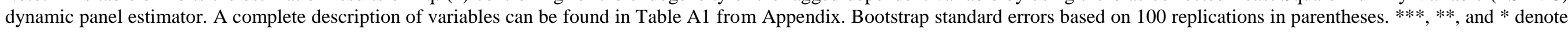
statistical significance at the $1 \%, 5 \%$ and $10 \%$, respectively. 
Table 3.

Estimation results including countries with fiscal council reforms.

\begin{tabular}{|c|c|c|c|c|c|c|c|c|c|c|c|c|c|c|c|}
\hline & \multicolumn{5}{|c|}{ Fiscal Balance } & \multicolumn{5}{|c|}{ Primary Balance } & \multicolumn{5}{|c|}{ Cyclically-Adjusted Fiscal Balance } \\
\hline \multirow{3}{*}{ Dependent (t-1) } & (1) & (2) & (3) & (4) & (5) & (1) & (2) & (3) & (4) & (5) & (1) & (2) & (3) & (4) & (5) \\
\hline & $0.7010^{* * * *}$ & $0.6958^{* * * *}$ & $0.6962^{* * * *}$ & $0.6877 * * * *$ & $0.7010 * * *$ & $0.6745^{* * * *}$ & $0.6739 * * *$ & $0.6754 * * *$ & $0.6698 * * *$ & $0.6745 * * *$ & $0.7413^{* * * *}$ & $0.7382^{* * * *}$ & $0.7437 * * *$ & $0.7352 * * *$ & $0.7413^{* * * *}$ \\
\hline & $(0.0439)$ & $(0.0436)$ & $(0.0428)$ & $(0.0469)$ & $(0.0439)$ & $(0.0434)$ & $(0.0431)$ & $(0.0430)$ & $(0.0469)$ & $(0.0434)$ & $(0.0381)$ & $(0.0436)$ & $(0.0418)$ & $(0.0423)$ & $(0.0381)$ \\
\hline \multirow{2}{*}{ Fiscal Council } & $0.9507 * * *$ & $0.9933 * * *$ & $1.0096^{* *}$ & $0.9963 * * *$ & $0.9507 * * *$ & $0.9079 * *$ & $0.9256^{* * *}$ & $0.9464 * *$ & $0.9447^{* *}$ & $0.9079 * *$ & $0.9664 * *$ & $1.0084 * *$ & $1.0264 * * *$ & $1.0108^{* * * *}$ & $0.9664 * *$ \\
\hline & $(0.3617)$ & $(0.3424)$ & $(0.4127)$ & $(0.3783)$ & $(0.3617)$ & $(0.3602)$ & $(0.3415)$ & $(0.4115)$ & $(0.3749)$ & $(0.3602)$ & $(0.3970)$ & $(0.4420)$ & $(0.3931)$ & $(0.3890)$ & $(0.3970)$ \\
\hline \multirow[t]{2}{*}{ Real GDP growth } & $0.1127 * * *$ & $0.1005 * *$ & $0.1010 * *$ & $0.1000 * *$ & $0.1127 * * *$ & $0.0836 * *$ & 0.0712 & $0.0734 *$ & 0.0725 & $0.0836 * *$ & $-0.1218^{* * * *}$ & $-0.1341 * * *$ & $-0.1341 * * *$ & $-0.1380^{* * *}$ & $-0.1218^{* * * *}$ \\
\hline & $(0.0395)$ & $(0.0485)$ & $(0.0392)$ & $(0.0464)$ & $(0.0395)$ & $(0.0394)$ & $(0.0484)$ & $(0.0391)$ & $(0.0463)$ & $(0.0394)$ & $(0.0414)$ & $(0.0445)$ & $(0.0413)$ & $(0.0479)$ & $(0.0414)$ \\
\hline \multirow[t]{2}{*}{ Gross Public Debt to GDP } & 0.0163 & 0.0151 & 0.0147 & 0.0125 & 0.0163 & $0.0288 * * *$ & $0.0294 * * *$ & $0.0282 * *$ & $0.0264 * *$ & $0.0288 * * *$ & 0.0107 & 0.0105 & 0.0093 & 0.0062 & 0.0107 \\
\hline & $(0.0107)$ & $(0.0095)$ & $(0.0115)$ & $(0.0111)$ & $(0.0107)$ & $(0.0106)$ & $(0.0095)$ & $(0.0115)$ & $\begin{array}{l}(0.0109) \\
\end{array}$ & $(0.0106)$ & $(0.0111)$ & $(0.0127)$ & $(0.0109)$ & $(0.0113)$ & $(0.0111)$ \\
\hline \multirow[t]{2}{*}{ Inflation } & 0.0405 & 0.0508 & 0.0339 & 0.0449 & 0.0405 & 0.0266 & 0.0368 & 0.0211 & 0.0267 & 0.0266 & 0.0582 & 0.0731 & 0.0540 & 0.0728 & 0.0582 \\
\hline & $(0.0409)$ & $(0.0451)$ & $(0.0400)$ & $(0.0556)$ & $(0.0409)$ & $(0.0407)$ & $\begin{array}{l}(0.0450) \\
\end{array}$ & $(0.0399)$ & $(0.0555)$ & $(0.0407)$ & $(0.0438)$ & $(0.0451)$ & $(0.0434)$ & $(0.0568)$ & $(0.0438)$ \\
\hline \multirow[t]{2}{*}{ Unemployment } & -0.0228 & -0.0212 & -0.0350 & -0.0516 & -0.0228 & -0.0511 & -0.0517 & -0.0618 & -0.0767 & -0.0511 & 0.0340 & 0.0420 & 0.0255 & 0.0075 & 0.0340 \\
\hline & $(0.0481)$ & $(0.0452)$ & $(0.0536)$ & $(0.0492)$ & $(0.0481)$ & $(0.0476)$ & $\begin{array}{l}(0.0454) \\
\end{array}$ & $(0.0539)$ & $\begin{array}{l}(0.0490) \\
\end{array}$ & $(0.0476)$ & $(0.0427)$ & $(0.0522)$ & $(0.0545)$ & $(0.0496)$ & $(0.0427)$ \\
\hline \multirow[t]{2}{*}{ Financial Openness } & & 0.4811 & & & & & 0.5907 & & & & & 0.8118 & & & \\
\hline & & $(0.9226)$ & & & & & $\begin{array}{l}(0.9105) \\
\end{array}$ & & & & & $(1.1239)$ & & & \\
\hline \multirow[t]{2}{*}{ Financial Development } & & & -3.5991 & & & & & -3.0310 & & & & & -3.4415 & & \\
\hline & & & $(2.9671)$ & & & & & $(2.9657)$ & & & & & $(3.2958)$ & & \\
\hline \multirow[t]{2}{*}{ Governance Index } & & & & -1.4209 & & & & & -1.0235 & & & & & -2.0241 & \\
\hline & & & & $(1.3971)$ & & & & & $(1.3759)$ & & & & & $(1.4455)$ & \\
\hline \multirow[t]{2}{*}{ Crisis } & & & & & $-3.1835^{* * * *}$ & & & & & $-3.6532 * * *$ & & & & & $-2.6061 * * *$ \\
\hline & & & & & $(0.6937)$ & & & & & $(0.6958)$ & & & & & $(0.6651)$ \\
\hline Observations & 513 & 468 & 486 & 459 & 513 & 513 & 468 & 486 & 459 & 513 & 512 & 467 & 485 & 459 & 512 \\
\hline Countries & 27 & 26 & 27 & 27 & 27 & 27 & 26 & 27 & 27 & 27 & 27 & 26 & 27 & 27 & 27 \\
\hline Year FE & Yes & Yes & Yes & Yes & Yes & Yes & Yes & Yes & Yes & Yes & Yes & Yes & Yes & Yes & Yes \\
\hline
\end{tabular}

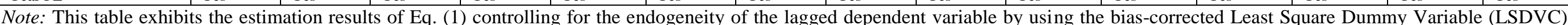

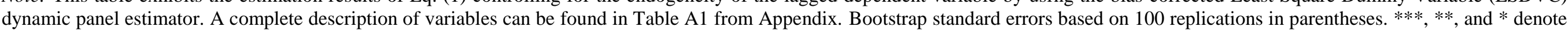
statistical significance at the $1 \%, 5 \%$ and $10 \%$, respectively. 
Table 4.

Estimation results: interactions considering different sample characteristics.

\begin{tabular}{|c|c|c|c|c|c|c|c|c|c|c|c|c|c|c|c|}
\hline & \multicolumn{5}{|c|}{ Fiscal Balance } & \multicolumn{5}{|c|}{ Primary Balance } & \multicolumn{5}{|c|}{ Cyclically-Adjusted Fiscal Balance } \\
\hline & (1) & (2) & (3) & (4) & (5) & (1) & (2) & (3) & (4) & (5) & (1) & (2) & (3) & (4) & (5) \\
\hline \multicolumn{16}{|c|}{ Interaction results: Old EU members. } \\
\hline \multirow{2}{*}{ Fiscal Council } & $0.8459 * *$ & $0.9320 * *$ & $1.0239 * *$ & $1.0785^{* *}$ & $0.8459 * *$ & $0.9217 * *$ & $0.9833 * *$ & $1.0682 * *$ & $1.1035^{* *}$ & $0.9217 * *$ & $0.7914 *$ & $0.8335 *$ & $0.9601 *$ & $1.0595^{* * *}$ & $0.7914 *$ \\
\hline & $(0.3882)$ & $(0.4277)$ & $(0.4242)$ & $(0.4439)$ & $(0.3882)$ & $(0.3857)$ & $(0.4253)$ & $(0.4224)$ & $(0.4436)$ & $(0.3857)$ & $(0.4109)$ & $(0.4650)$ & $(0.4948)$ & $(0.4567)$ & $(0.4109)$ \\
\hline \multirow[t]{2}{*}{ Fiscal Council $\times$ Old EU } & -0.1547 & -0.0502 & -0.0921 & -0.2782 & -0.1547 & -0.3041 & -0.2257 & -0.2343 & -0.3709 & -0.3041 & 0.0360 & 0.2391 & 0.1172 & -0.1413 & 0.0360 \\
\hline & $(0.4946)$ & $(0.5231)$ & $(0.4971)$ & $(0.5082)$ & $(0.4946)$ & $(0.4898)$ & $(0.5217)$ & $(0.4938)$ & $(0.5044)$ & $(0.4898)$ & $(0.4276)$ & $(0.5678)$ & $(0.5408)$ & $(0.5251)$ & $(0.4276)$ \\
\hline \multicolumn{16}{|c|}{ Interaction results: New EU members. } \\
\hline \multirow[t]{2}{*}{ Fiscal Council } & $0.6912 *$ & $0.8819^{*}$ & $0.9318^{* * *}$ & $0.8003^{*}$ & $0.6912 *$ & 0.6176 & 0.7576 & $0.8339 *$ & $0.7325^{*}$ & 0.6176 & $0.8274^{*}$ & $1.0726^{* * *}$ & $1.0773 * *$ & $0.9183 * *$ & $0.8274^{*}$ \\
\hline & $(0.4012)$ & $(0.4650)$ & $(0.4416)$ & $(0.4195)$ & $(0.4012)$ & $(0.3990)$ & $(0.4642)$ & $(0.4406)$ & $(0.4158)$ & $(0.3990)$ & $(0.4465)$ & $(0.5083)$ & $(0.4721)$ & $(0.4301)$ & $(0.4465)$ \\
\hline \multirow[t]{2}{*}{ Fiscal Council $\times$ New EU } & 0.1547 & 0.0502 & 0.0921 & 0.2782 & 0.1547 & 0.3041 & 0.2257 & 0.2343 & 0.3709 & 0.3041 & -0.0360 & -0.2391 & -0.1172 & 0.1413 & -0.0360 \\
\hline & $(0.4946)$ & $(0.5231)$ & $(0.4971)$ & $(0.5082)$ & $(0.4946)$ & $(0.4898)$ & $(0.5217)$ & $(0.4938)$ & $(0.5044)$ & $(0.4898)$ & $(0.4276)$ & $(0.5678)$ & $(0.5408)$ & $(0.5251)$ & $(0.4276)$ \\
\hline \multicolumn{16}{|c|}{ Interaction results: Non-euro area members. } \\
\hline \multirow[t]{2}{*}{ Fiscal Council } & $0.9800 * *$ & $1.1366 * *$ & $1.3249 * * *$ & $1.2286 * *$ & $0.9800^{* * *}$ & $1.0795 * *$ & $1.2129 * *$ & $1.3868 * * *$ & $1.2881^{* * * *}$ & $1.0795 * *$ & $1.0826^{* * *}$ & $1.2091 * *$ & $1.4091 * *$ & $1.3165^{* * *}$ & $1.0826^{* * *}$ \\
\hline & $\begin{array}{l}(0.4308) \\
\end{array}$ & $\begin{array}{l}(0.5068) \\
\end{array}$ & $(0.5137)$ & $\begin{array}{l}(0.4872) \\
\end{array}$ & $\begin{array}{l}(0.4308) \\
\end{array}$ & $(0.4253)$ & $(0.5054)$ & $(0.5121)$ & $(0.4864)$ & $\begin{array}{l}(0.4253) \\
\end{array}$ & $\begin{array}{l}(0.4744) \\
\end{array}$ & $(0.5585)$ & $(0.5946)$ & $(0.4994)$ & $(0.4744)$ \\
\hline \multirow[t]{2}{*}{ Fiscal Council $\times$ EA } & -0.3476 & -0.3887 & -0.5434 & -0.4549 & -0.3476 & -0.4833 & -0.5523 & -0.6658 & -0.5719 & -0.4833 & -0.4465 & -0.4348 & -0.6152 & -0.5144 & -0.4465 \\
\hline & $(0.5036)$ & $(0.5534)$ & $(0.5533)$ & $(0.4898)$ & $(0.5036)$ & $(0.4979)$ & $(0.5498)$ & $(0.5499)$ & $(0.4856)$ & $(0.4979)$ & $(0.4798)$ & $(0.5476)$ & $(0.5714)$ & $(0.5031)$ & $(0.4798)$ \\
\hline \multicolumn{16}{|c|}{ Interaction results: Non-euro area members. } \\
\hline \multirow[t]{2}{*}{ Fiscal Council } & $0.6324 *$ & $0.7479 *$ & $0.7815^{*}$ & $0.7736^{* *}$ & $0.6324 *$ & 0.5962 & 0.6606 & $0.7211^{*}$ & $0.7162 *$ & 0.5962 & 0.6361 & $0.7743 *$ & $0.7938^{*}$ & $0.8021 * *$ & 0.6361 \\
\hline & $(0.3727)$ & $(0.4177)$ & $\begin{array}{l}(0.4021) \\
\end{array}$ & $(0.3764)$ & $(0.3727)$ & $(0.3705)$ & $\begin{array}{l}(0.4138) \\
\end{array}$ & $(0.4002)$ & $(0.3731)$ & $(0.3705)$ & $(0.4180)$ & $(0.4214)$ & $\begin{array}{l}(0.4174) \\
\end{array}$ & $(0.3861)$ & $(0.4180)$ \\
\hline \multirow[t]{2}{*}{ Fiscal Council $\times$ Non-EA } & 0.3476 & 0.3887 & 0.5434 & 0.4549 & 0.3476 & 0.4833 & 0.5523 & 0.6658 & 0.5719 & 0.4833 & 0.4465 & 0.4348 & 0.6152 & 0.5144 & 0.4465 \\
\hline & $(0.5036)$ & $(0.5534)$ & $(0.5533)$ & $(0.4898)$ & $(0.5036)$ & $(0.4979)$ & $(0.5498)$ & $(0.5499)$ & $(0.4856)$ & $(0.4979)$ & $(0.4798)$ & $(0.5476)$ & $(0.5714)$ & $(0.5031)$ & $(0.4798)$ \\
\hline Controls & Yes & Yes & Yes & Yes & Yes & Yes & Yes & Yes & Yes & Yes & Yes & Yes & Yes & Yes & Yes \\
\hline Observations & 513 & 468 & 486 & 459 & 513 & 513 & 468 & 486 & 459 & 513 & 512 & 467 & 485 & 459 & 512 \\
\hline Countries & 27 & 26 & 27 & 27 & 27 & 27 & 26 & 27 & 27 & 27 & 27 & 26 & 27 & 27 & 27 \\
\hline Year FE & Yes & Yes & Yes & Yes & Yes & Yes & Yes & Yes & Yes & Yes & Yes & Yes & Yes & Yes & Yes \\
\hline
\end{tabular}

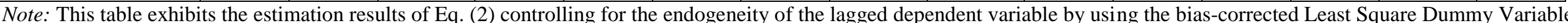

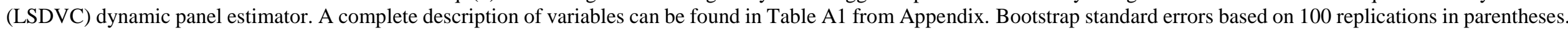
$* * *, * *$, and $*$ denote statistical significance at the $1 \%, 5 \%$ and $10 \%$, respectively. 
Table 5.

Estimation results for fiscal councils established before 2013 .

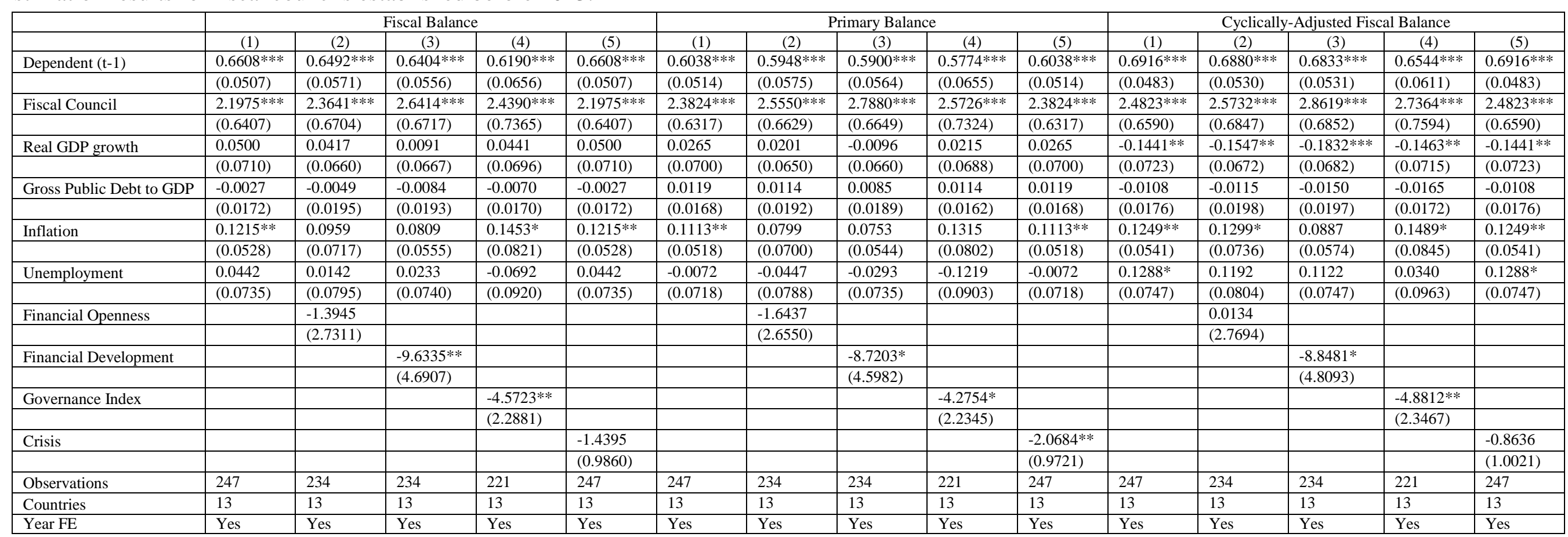

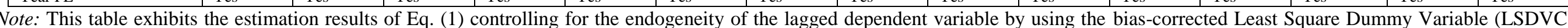

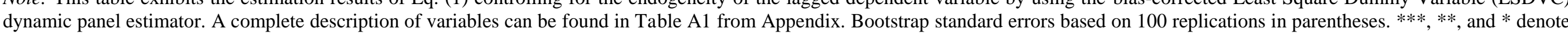
statistical significance at the $1 \%, 5 \%$ and $10 \%$, respectively. 
Table 6.

Estimation results for fiscal councils established in or after 2013.

\begin{tabular}{|c|c|c|c|c|c|c|c|c|c|c|c|c|c|c|c|}
\hline & \multicolumn{5}{|c|}{ Fiscal Balance } & \multicolumn{5}{|c|}{ Primary Balance } & \multicolumn{5}{|c|}{ Cyclically-Adjusted Fiscal Balance } \\
\hline & (1) & (2) & (3) & (4) & (5) & (1) & (2) & (3) & (4) & (5) & (1) & (2) & (3) & (4) & (5) \\
\hline \multirow[t]{2}{*}{ Dependent (t-1) } & $0.6521 * * *$ & 0.6497 **** & $0.6591 * * *$ & $0.6038^{* * * *}$ & $0.6521 * * *$ & $0.6660^{* * * *}$ & $0.6711 * * *$ & $0.6782^{* * * *}$ & $0.6034 * * *$ & $0.6660^{* * * *}$ & $0.6717 * * *$ & $0.6689 * * *$ & $0.6850^{* * * *}$ & $0.6461 * * *$ & $0.6717 * * * *$ \\
\hline & $(0.0521)$ & $(0.0630)$ & $(0.0624)$ & $(0.0591)$ & $(0.0521)$ & $(0.0508)$ & $(0.0623)$ & $(0.0613)$ & $(0.0588)$ & $(0.0508)$ & $(0.0593)$ & $(0.0630)$ & $(0.0634)$ & $(0.0605)$ & $(0.0593)$ \\
\hline Fiscal Council & -0.3734 & -0.4252 & -0.3882 & -0.3217 & -0.3734 & -0.5631 & -0.6241 & -0.5909 & -0.5308 & -0.5631 & -0.4563 & -0.5036 & -0.4728 & -0.4099 & -0.4563 \\
\hline \multirow[t]{2}{*}{ Real GDP growth } & $0.2072 * * *$ & $0.1914 * * *$ & $0.2027 * * *$ & $0.2213^{* * *}$ & $0.2072 * * *$ & $0.1725 * * *$ & $0.1556^{* * *}$ & $0.1680^{* * *}$ & $0.1930^{* * *}$ & $0.1725^{* * *}$ & -0.0422 & -0.0556 & -0.0485 & -0.0414 & -0.0422 \\
\hline & $(0.0446)$ & $(0.0479)$ & $(0.0506)$ & $(0.0617)$ & $(0.0446)$ & $(0.0451)$ & $(0.0488)$ & $(0.0509)$ & $(0.0626)$ & $(0.0451)$ & $(0.0577)$ & $(0.0545)$ & $(0.0525)$ & $(0.0644)$ & $(0.0577)$ \\
\hline \multirow[t]{2}{*}{ Gross Public Debt to GDP } & 0.0129 & 0.0178 & 0.0106 & 0.0028 & 0.0129 & 0.0231 & $0.0288^{*}$ & 0.0207 & 0.0144 & 0.0231 & 0.0065 & 0.0115 & 0.0039 & -0.0036 & 0.0065 \\
\hline & $(0.0140)$ & $(0.0156)$ & $(0.0168)$ & $(0.0175)$ & $(0.0140)$ & $(0.0144)$ & $(0.0160)$ & $(0.0172)$ & $(0.0178)$ & $(0.0144)$ & $(0.0136)$ & $(0.0172)$ & $(0.0146)$ & $(0.0184)$ & $(0.0136)$ \\
\hline \multirow[t]{2}{*}{ Inflation } & -0.0812 & -0.0744 & -0.0754 & -0.0606 & -0.0812 & -0.0874 & -0.0818 & -0.0813 & -0.0726 & -0.0874 & -0.0479 & -0.0413 & -0.0383 & -0.0163 & -0.0479 \\
\hline & $(0.0573)$ & $(0.0543)$ & $(0.0614)$ & $(0.0701)$ & $(0.0573)$ & $(0.0581)$ & $(0.0551)$ & $(0.0619)$ & $(0.0713)$ & $(0.0581)$ & $(0.0546)$ & $(0.0613)$ & $(0.0607)$ & $(0.0736)$ & $(0.0546)$ \\
\hline \multirow[t]{2}{*}{ Unemployment } & -0.0763 & -0.0914 & -0.0698 & -0.0194 & -0.0763 & -0.0726 & -0.0889 & -0.0621 & -0.0166 & -0.0726 & -0.0023 & -0.0105 & 0.0068 & 0.0550 & -0.0023 \\
\hline & $(0.0543)$ & $(0.0665)$ & $(0.0585)$ & $(0.0734)$ & $(0.0543)$ & $(0.0555)$ & $(0.0678)$ & $(0.0595)$ & $(0.0743)$ & $(0.0555)$ & $(0.0470)$ & $(0.0634)$ & $(0.0640)$ & $(0.0730)$ & $(0.0470)$ \\
\hline \multirow[t]{2}{*}{ Financial Openness } & & 1.0293 & & & & & 1.0156 & & & & & 1.1952 & & & \\
\hline & & $(0.9198)$ & & & & & $(0.9283)$ & & & & & $(0.9273)$ & & & \\
\hline \multirow[t]{2}{*}{ Financial Development } & & & -0.3256 & & & & & 0.0818 & & & & & $\begin{array}{l}-0.2241 \\
\end{array}$ & & \\
\hline & & & (3.9812) & & & & & $(4.0265)$ & & & & & $(4.0227)$ & & \\
\hline \multirow[t]{2}{*}{ Governance Index } & & & & 3.2011 & & & & & $3.5400 *$ & & & & & 1.7795 & \\
\hline & & & & $(2.0118)$ & & & & & $(2.0258)$ & & & & & $(2.1111)$ & \\
\hline Crisis & & & & & -0.6254 & & & & & -0.9612 & & & & & $-1.5364^{*}$ \\
\hline Observations & 266 & 234 & 252 & 238 & 266 & 266 & 234 & 252 & 238 & 266 & 265 & 233 & 251 & 238 & 265 \\
\hline Countries & 14 & 13 & 14 & 14 & 14 & 14 & 13 & 14 & 14 & 14 & 14 & 13 & 14 & 14 & 14 \\
\hline Year FE & Yes & Yes & Yes & Yes & Yes & Yes & Yes & Yes & Yes & Yes & Yes & Yes & Yes & Yes & Yes \\
\hline
\end{tabular}

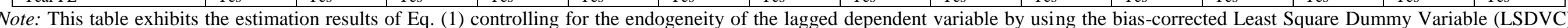

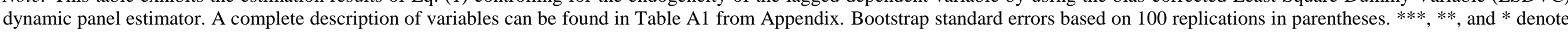
statistical significance at the $1 \%, 5 \%$ and $10 \%$, respectively. 
Table 7.

Estimation results: interaction with systemic and banking crisis.

\begin{tabular}{|c|c|c|c|c|c|c|c|c|c|c|c|c|c|c|c|}
\hline & \multicolumn{5}{|c|}{ Fiscal Balance } & \multicolumn{5}{|c|}{ Primary Balance } & \multicolumn{5}{|c|}{ Cyclically-Adjusted Fiscal Balance } \\
\hline & $(1)$ & $(2)$ & (3) & (4) & (5) & (1) & $(2)$ & (3) & (4) & (5) & (1) & $(2)$ & (3) & (4) & (5) \\
\hline \multicolumn{16}{|c|}{ Interaction results: Systemic Crisis. } \\
\hline \multirow[t]{2}{*}{ Fiscal Council } & $0.5575^{*}$ & $0.6437 *$ & $0.7366 * *$ & $0.6933 * *$ & $0.5575^{*}$ & $0.5862 *$ & $0.6410^{*}$ & $0.7405 * *$ & $0.6926^{* *}$ & $0.5862 *$ & 0.5791 & $0.6729 *$ & $0.7619 *$ & $0.7315^{* *}$ & 0.5791 \\
\hline & $(0.3179)$ & $(0.3852)$ & $(0.3689)$ & $(0.3499)$ & $(0.3179)$ & $(0.3154)$ & $(0.3850)$ & $(0.3692)$ & $(0.3493)$ & $(0.3154)$ & $(0.3827)$ & $(0.3971)$ & $(0.4107)$ & $(0.3597)$ & $(0.3827)$ \\
\hline \multirow[t]{2}{*}{ Fiscal Council $\times$ Systemic Crisis } & $0.6743^{*}$ & $0.8462^{* * *}$ & $0.7385^{*}$ & $0.7931 *$ & $0.6743^{*}$ & 0.5894 & $0.7440^{* * *}$ & 0.6396 & 0.7131 & 0.5894 & $0.7411^{* *}$ & $0.9047 * *$ & $0.7906^{* * *}$ & $0.8405^{*}$ & $0.7411^{\text {**: }}$ \\
\hline & $0.5575^{*}$ & $0.6437^{*}$ & $0.7366 * *$ & $0.6933 * *$ & $0.5575^{*}$ & $(0.3671)$ & $(0.3375)$ & $(0.4078)$ & $(0.4425)$ & $(0.3671)$ & $(0.3749)$ & $(0.4324)$ & $(0.3530)$ & $(0.4632)$ & $(0.3749)$ \\
\hline Observations & 513 & 468 & 486 & 459 & 513 & 513 & 468 & 486 & 459 & 513 & 512 & 467 & 485 & 459 & 512 \\
\hline \multicolumn{16}{|c|}{ Interaction results: Banking Crisis. } \\
\hline \multirow[t]{2}{*}{ Fiscal Council } & $0.6620^{*}$ & $0.6793^{*}$ & $0.7544 *$ & $0.7236^{*}$ & $0.6620^{*}$ & 0.6045 & $0.6039 *$ & $0.6789^{*}$ & 0.6453 & 0.6045 & 0.6760 & $0.6859^{*}$ & $0.7617^{*}$ & $0.7346^{*}$ & 0.6760 \\
\hline & $(0.3736)$ & $(0.3621)$ & $(0.3859)$ & $(0.4359)$ & $(0.3736)$ & $(0.3728)$ & $(0.3613)$ & $(0.3864)$ & $(0.4362)$ & $(0.3728)$ & $(0.4403)$ & $(0.4164)$ & $(0.4583)$ & $(0.4436)$ & $(0.4403)$ \\
\hline \multirow[t]{2}{*}{ Fiscal Council $\times$ Banking Crisis } & $1.0096^{* * *}$ & $1.0439^{* * *}$ & $0.9498^{* *}$ & $1.0181 * *$ & $1.0096^{* *}$ & $1.1173^{* * *}$ & $1.1520 * *$ & $1.0699 * *$ & $1.1564 * *$ & $1.1173^{* *}$ & $1.1220^{* * *}$ & $1.1577 * * *$ & $1.0686^{* * *}$ & $1.1493^{* *}$ & $1.1220^{\text {**: }}$ \\
\hline & $\begin{array}{l}(0.4771) \\
\end{array}$ & $(0.5005)$ & $(0.4815)$ & $\begin{array}{l}(0.4807) \\
\end{array}$ & $\begin{array}{l}(0.4771) \\
\end{array}$ & $\begin{array}{l}(0.4750) \\
\end{array}$ & $\begin{array}{l}(0.4974) \\
\end{array}$ & $\begin{array}{l}(0.4803) \\
\end{array}$ & $\begin{array}{l}(0.4777) \\
\end{array}$ & $(0.4750)$ & (0.4646) & $(0.4140)$ & $\begin{array}{l}(0.4624) \\
\end{array}$ & $\begin{array}{l}(0.4941) \\
\end{array}$ & $(0.4646)$ \\
\hline Controls & Yes & Yes & Yes & Yes & Yes & Yes & Yes & Yes & Yes & Yes & Yes & Yes & Yes & Yes & Yes \\
\hline Observations & 459 & 442 & 459 & 432 & 459 & 459 & 442 & 459 & 432 & 459 & 458 & 441 & 458 & 432 & 458 \\
\hline Countries & 27 & 26 & 27 & 27 & 27 & 27 & 26 & 27 & 27 & 27 & 27 & 26 & 27 & 27 & 27 \\
\hline Year FE & Yes & Yes & Yes & Yes & Yes & Yes & Yes & Yes & Yes & Yes & Yes & Yes & Yes & Yes & Yes \\
\hline
\end{tabular}

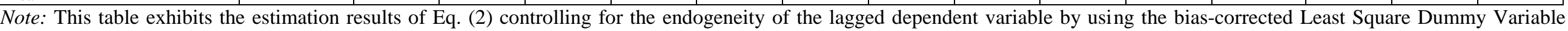

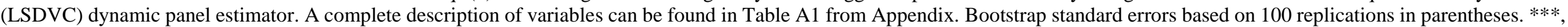
$* *$, and $*$ denote statistical significance at the $1 \%, 5 \%$ and $10 \%$, respectively. 


\section{APPENDIX}

Table A1.

Definition of variables.

\begin{tabular}{|c|c|c|}
\hline Variable & Definition & Source \\
\hline \multicolumn{3}{|c|}{ Dependent variables } \\
\hline Fiscal Balance & $\begin{array}{l}\text { The difference between } \\
\text { government revenues and } \\
\text { government expenses as a percent } \\
\text { of GDP }\end{array}$ & AMECO \\
\hline Primary Balance & $\begin{array}{l}\text { The difference between } \\
\text { government revenues and } \\
\text { government expenses net of the } \\
\text { public sector debt interest } \\
\text { expenditure as a percent of GDP }\end{array}$ & AMECO \\
\hline $\begin{array}{l}\text { Cyclically-Adjusted Fiscal } \\
\text { Balance } \\
\text { (Structural Balance) }\end{array}$ & $\begin{array}{l}\text { The difference between } \\
\text { government revenues and } \\
\text { government expenses as a percent } \\
\text { of potential GDP }\end{array}$ & AMECO \\
\hline \multicolumn{3}{|c|}{ Independent variables } \\
\hline Fiscal Council & $\begin{array}{l}\text { Dummy variable that takes the } \\
\text { value of } 1 \text { if the fiscal council in a } \\
\text { particular year was established and } \\
\text { afterwards, and } 0 \text { otherwise }\end{array}$ & $\begin{array}{l}\text { Debrun et al. (2016); Căpraru and } \\
\text { Georgescu (2020), own } \\
\text { calculation }\end{array}$ \\
\hline Real GDP growth & $\begin{array}{l}\text { Annual percentage growth rate of } \\
\text { GDP at market prices based on } \\
\text { constant local currency }\end{array}$ & $\begin{array}{l}\text { World Development Indicators } \\
\text { (WDI) }\end{array}$ \\
\hline Gross Public Debt to GDP & $\begin{array}{l}\text { Government gross debt as a } \\
\text { percent of GDP }\end{array}$ & AMECO \\
\hline Inflation & $\begin{array}{l}\text { Inflation as measured by the annual } \\
\text { growth rate of the GDP implicit } \\
\text { deflator shows the rate of price } \\
\text { change in the economy as a whole. } \\
\text { The GDP implicit deflator is the } \\
\text { ratio of GDP in current local } \\
\text { currency to GDP in constant local } \\
\text { currency }\end{array}$ & $\begin{array}{l}\text { World Development Indicators } \\
\text { (WDI) }\end{array}$ \\
\hline Unemployment & $\begin{array}{l}\text { The share of the labor force that is } \\
\text { without work but available for and } \\
\text { seeking employment }\end{array}$ & AMECO \\
\hline \multicolumn{3}{|c|}{ Additional control variables } \\
\hline Financial Openness & $\begin{array}{l}\text { Financial openness index is } \\
\text { defined as the degree of capital } \\
\text { account openness. A higher index } \\
\text { value implies more open a } \\
\text { particular country is to cross- } \\
\text { border capital transactions }\end{array}$ & Chinn and Ito (2008) \\
\hline Financial Development & $\begin{array}{l}\text { Index constructed using using } \\
\text { indicators of financial depth, } \\
\text { access, and efficiency for financial } \\
\text { institutions and markets. Higher } \\
\text { levels of the index are associated }\end{array}$ & Sahay et al. (2015) \\
\hline
\end{tabular}




\begin{tabular}{|c|c|c|}
\hline & $\begin{array}{l}\text { with increased financial } \\
\text { development }\end{array}$ & \\
\hline Governance Index & $\begin{array}{l}\text { Index constructed as the weighted- } \\
\text { average of the Worldwide } \\
\text { Governance Indicators (WGI): (i) } \\
\text { voice and accountability; (ii) } \\
\text { political stability and absence of } \\
\text { violence; (iii) government } \\
\text { effectiveness; (iv) regulatory } \\
\text { quality; (v) rule of law; and (vi) } \\
\text { control of corruption. A higher } \\
\text { index value implies higher degree } \\
\text { of governance }\end{array}$ & Kaufmann and Kraay (2011) \\
\hline Global Crisis & $\begin{array}{l}\text { Dummy variable that takes the } \\
\text { value of } 1 \text { if the year is before } \\
2008 \text {, and } 0 \text { otherwise }\end{array}$ & Own calculation \\
\hline \multicolumn{3}{|c|}{ Interaction variables } \\
\hline Old EU & $\begin{array}{l}\text { Dummy variable that takes the } \\
\text { value of } 1 \text { if a particular country } \\
\text { joined the European Union before } \\
2004 \text {, and } 0 \text { otherwise }\end{array}$ & Own calculations \\
\hline New EU & $\begin{array}{l}\text { Dummy variable that takes the } \\
\text { value of } 1 \text { if a particular country } \\
\text { joined the European Union starting } \\
\text { with } 2004 \text {, and } 0 \text { otherwise }\end{array}$ & Own calculations \\
\hline EA & $\begin{array}{l}\text { Dummy variable that takes the } \\
\text { value of } 1 \text { if a particular country } \\
\text { joined the euro area at time } t \text { and } \\
\text { afterwards, and } 0 \text { otherwise }\end{array}$ & Own calculations \\
\hline Non-EA & $\begin{array}{l}\text { Dummy variable that takes the } \\
\text { value of } 1 \text { if a particular country is } \\
\text { not a member of the euro area, and } \\
0 \text { otherwise }\end{array}$ & Own calculations \\
\hline Systemic Crisis & $\begin{array}{l}\text { Dummy variable that takes the } \\
\text { value of } 1 \text { if a country experienced } \\
\text { a systemic crisis in a particular } \\
\text { year, and } 0 \text { otherwise }\end{array}$ & Lo Duca et al. (2017) \\
\hline Banking Crisis & $\begin{array}{l}\text { Dummy variable that takes the } \\
\text { value of } 1 \text { if a country experienced } \\
\text { a systemic banking crisis in a } \\
\text { particular year, and } 0 \text { otherwise }\end{array}$ & Laeven and Valencia (2020) \\
\hline
\end{tabular}


Table A2.

Sample used in the empirical analysis.

\begin{tabular}{|c|c|c|c|c|}
\hline $\begin{array}{l}\text { Nr. } \\
\text { crt. }\end{array}$ & Country name & $\begin{array}{l}\text { Year of establishment of } \\
\text { Fiscal Council }\end{array}$ & $\begin{array}{l}\text { Euro Area Member in } \\
2019\end{array}$ & $\begin{array}{l}\text { Year of reform of Fiscal } \\
\text { Council }\end{array}$ \\
\hline 1 & Austria & 1970 & Yes & 2013 \\
\hline 2 & Belgium & 1989 & Yes & 2013 \\
\hline 3 & Bulgaria & 2015 & No & \\
\hline 4 & Croatia & 2013 & No & \\
\hline 5 & Cyprus & 2014 & Yes & \\
\hline 6 & Czech Republic & 2018 & No & \\
\hline 7 & Denmark & 1962 & No & 2014 \\
\hline 8 & Estonia & 2014 & Yes & \\
\hline 9 & Finland & 2013 & Yes & \\
\hline 10 & France & 2013 & Yes & \\
\hline 11 & Germany & 2010 & Yes & \\
\hline 12 & Greece & 2010 & Yes & \\
\hline 13 & Hungary & 2009 & No & \\
\hline 14 & Ireland & 2011 & Yes & \\
\hline 15 & Italy & 2014 & Yes & \\
\hline 16 & Latvia & 2014 & Yes & \\
\hline 17 & Lithuania & 2015 & Yes & \\
\hline 18 & Luxembourg & 2014 & Yes & \\
\hline 19 & Malta & 2015 & Yes & \\
\hline 20 & Netherlands & 1945 & Yes & 2013 \\
\hline 21 & Portugal & 2012 & Yes & \\
\hline 21 & Romania & 2010 & No & \\
\hline 23 & Slovak Republic & 2011 & Yes & \\
\hline 24 & Slovenia & 2017 & Yes & \\
\hline 25 & Spain & 2014 & Yes & \\
\hline 26 & Sweden & 2007 & Yes & \\
\hline 27 & United Kingdom & 2010 & No & \\
\hline
\end{tabular}


Table A3.

Correlation matrix.

\begin{tabular}{|c|c|c|c|c|c|c|c|c|c|c|c|c|}
\hline Variables & (1) & (2) & (3) & (4) & (5) & (6) & (7) & (8) & (9) & (10) & (11) & (12) \\
\hline (1) Fiscal Balance & 1.0000 & & & & & & & & & & & \\
\hline (2) Primary Balance & $0.9280^{*}$ & 1.0000 & & & & & & & & & & \\
\hline (3) Cyclically-Adjusted Balance & $0.8875^{*}$ & $0.8340^{*}$ & 1.0000 & & & & & & & & & \\
\hline (4) Fiscal Council dummy & $0.1807 *$ & $0.2196^{*}$ & $0.2602 *$ & 1.0000 & & & & & & & & \\
\hline (5) Real GDP growth & $0.3816^{*}$ & $0.3195 *$ & $0.1258^{*}$ & -0.0600 & 1.0000 & & & & & & & \\
\hline (6) Gross Debt to GDP & $-0.3624 *$ & $-0.0734 *$ & $-0.1990^{*}$ & $0.3395 *$ & $-0.3090 *$ & 1.0000 & & & & & & \\
\hline (7) Inflation & $0.1464 *$ & $0.1069^{*}$ & -0.0278 & $-0.2529 *$ & $0.3837 *$ & $-0.3575^{*}$ & 1.0000 & & & & & \\
\hline (8) Unemployment & $-0.4079 *$ & $-0.3383^{*}$ & $-0.1508^{*}$ & $-0.0831^{*}$ & $-0.1746^{*}$ & $0.3797^{*}$ & $-0.2024 *$ & 1.0000 & & & & \\
\hline (9) Financial Openness & $0.0932 *$ & 0.0657 & $0.0775^{*}$ & $0.2251 *$ & $-0.1082 *$ & 0.0700 & $-0.2297 *$ & $-0.2541^{*}$ & 1.0000 & & & \\
\hline (10) Financial Development Index & -0.0154 & $0.0916^{*}$ & 0.0239 & $0.1869^{*}$ & $-0.2624 *$ & $0.4031^{*}$ & $-0.3619 *$ & $-0.1817^{*}$ & $0.4050^{*}$ & 1.0000 & & \\
\hline (11) Governance Index & $0.2518^{*}$ & $0.2178^{*}$ & $0.2424 *$ & $0.1939^{*}$ & -0.0603 & $-0.0990^{*}$ & $-0.2837 *$ & $-0.4356^{*}$ & $0.3401 *$ & $0.6136^{*}$ & 1.0000 & \\
\hline (12) Crisis & $-0.1499 *$ & $-0.2092 *$ & 0.0218 & $0.4899 *$ & $-0.3544 *$ & $0.2613 *$ & $-0.3261 *$ & $0.1179^{*}$ & $0.2091 *$ & 0.0414 & -0.0565 & 1.0000 \\
\hline
\end{tabular}

Note: This table exhibits the correlation matrix of the variables used in the empirical analysis. A complete description of variables can be found in Table A1 from Appendix. * denote statistical significance at the maximum level of significance of $10 \%$. 